\title{
Environmental Impact of Abattoir Waste Discharge on the Quality of Surface Water and Ground Water in Abeokuta
}

\author{
Ojekunle OZ* and Lateef ST
}

Federal University of Agriculture, Abeokuta, Ogun State, Nigeria

\begin{abstract}
The problem of getting quality water is increasing as untreated effluents are discharged into water bodies. The study aims at assessing the impact of various abattoirs wastewater on ground and surface water bodies in Abeokuta. Water samples were collected randomly in 9 different locations of Abeokuta ( 4 stream and 3 groundwater samples as well and 2 around abattoir vicinity as controls of surface and groundwater). All the samples were collected on the same day in the morning and were analysed for physical, chemical and microbiological load. The water quality parameters measured includes; Colour, Odour, pH, EC, Temperature, TDS, $\mathrm{C}_{12}$, DO, BOD, COD, TS, TSS, $\mathrm{NO}_{3}, \mathrm{PO}_{4}$, Heavy Metals $(\mathrm{Pb}, \mathrm{Zn}$, $\mathrm{Cu}, \mathrm{Cd}, \mathrm{Fe})$, microbiological analysis. The parameters were analysed using standard procedures and the results were analysed using descriptive and inferential statistics. The ranges of the means values of all the parameters measured for $\mathrm{pH}$, Temperature, Hardness, TDS, $\mathrm{C}_{12}, \mathrm{NO}_{3}, \mathrm{PO}_{4}, \mathrm{BOD}_{5}$, DO, COD, TS and TSS were $7.23-7.36,27.3^{\circ} \mathrm{C}-28.0^{\circ} \mathrm{C}, 164-$ $323 \mathrm{mg} / \mathrm{L}, 102-518 \mathrm{mg} / \mathrm{L}, 20-70 \mathrm{mg} / \mathrm{L}, 0.005-0.706 \mathrm{mg} / \mathrm{L}, 0.212-0.850 \mathrm{mg} / \mathrm{L}, 0.570-7.400 \mathrm{mg} / \mathrm{L}, 1.0-6.8 \mathrm{mg} / \mathrm{L}, 72-504$ $\mathrm{mg} / \mathrm{L}, 0.260-0.520 \mathrm{mg} / \mathrm{L}, 15.4-16.1 \mathrm{mg} / \mathrm{L}$ and that of heavy metal were; $0.03-0.19 \mathrm{mg} / \mathrm{L}, 0.020-0.090 \mathrm{mg} / \mathrm{L}, 0.010-0.030$ $\mathrm{mg} / \mathrm{L}, 0.0-0.700 \mathrm{mg} / \mathrm{L}, 0.040-4.960 \mathrm{mg} / \mathrm{L}$ for $\mathrm{Pb}, \mathrm{Zn}, \mathrm{Cu}, \mathrm{Cd}$, Fe respectively while that of the Faecal Coliform was 100$300 \mathrm{cfu} / \mathrm{ml}$ respectively. The results of the study revealed that all of the measured parameters show significant difference in their mean except $\mathrm{C}_{12}, \mathrm{EC}, \mathrm{PO}_{4}$ TDS and Temperature. From the results, it was discovered that the concentration of Hardness, $\mathrm{Pb}, \mathrm{Cu}, \mathrm{Pb}, \mathrm{Zn}, \mathrm{Cd}, \mathrm{Fe}$ and Faecal Coliform exceeded the permissible limits of both the WHO and FEPA standard for drinking and wastewater effluent. Pollution of ground and surface water through discharge of waste is an evidenced by the high concentrations of pollution indicators, nutrients and trace metals above the acceptable limits.
\end{abstract}

Keywords: Abattoir; Faecal coliform; Monitoring; Pollution; Quality; Waste water

\section{Introduction}

Water is a universal resource because of its free nature, is often subject to abused, especially in the third world nations where information is not disseminated to society. Water can be gotten everywhere but safe and clean water are hard to come by in almost all part of the world [1]. Water performs three roles of transporting body nutrients to other vital organs, regulating the body temperature, as well as carrying waste out of our internal body organs and is second only to air in its importance. The highest rate that water is potentially available for human use and its management is often considered the best measure of the total water resources in any given region. The physical hazards presents are the VOCs, dissolved solids and suspended solids etc. The chemicals hazards are the iron, mercury, copper, manganese, lead, cadmium, phosphate, nitrate etc.

Surface and ground water are separate two entities requiring ever increasing need for management. Surface and ground water is the most readily available, yet the most polluted as a result of anthropogenic activities, but notably, controllable activities. In developing countries, especially the rural areas where potable water supply is a near rarity, most of the dwellers rely mainly on water in streams, brooks, rivers, ponds and lakes, well, borehole, tube wells. Groundwater is characterized with adequate aquifer protection, groundwater has excellent microbial and chemical quality and it therefore requires minimal or no treatment. Also, the capital cost of groundwater development when compared to surface water development is modest and groundwater lends itself to flexible development make it attractive as a source of potable water supply. The wells terminate in the weathered crystalline rocks and if deep enough could sustain the dry season.

Formerly, the main source of water to the residing people in Abeokuta is the public water supply through Ogun state water corporation, the water supply situation in the city seemed to be deteriorating and retarding due to the continuous increase in the population and industrial growth. The poor and inadequate network has led to water shortage in some areas in Abeokuta. The major substitutes for pipe borne water are shallow hand dug wells in areas of low and average income. The principal sources and causes of groundwater pollution are municipal, industrial, agricultural and others.

Abattoir activities may be another source of pollution since human activities such as animal production and meat processing have been reported to impact negatively on soil and natural water composition leading to pollution of the soil, natural water resources and the entire environment [2]. It has also been reported that animals which graze on contaminated plants and drink from polluted waters, as well as marine lives that breed in heavy metal polluted waters also accumulate such metals in their tissues and milk if lactating. When such animals are killed, these metals are released in the soil as natural sink but subsequently leached out into nearby streams or water bodies.

Abattoir wastes usually are multi-dimensional, mainly organics containing fat, grease, hair, feathers, grit, flesh, manure, and undigested feed, blood, bones and process water [3,4]. World Bank, 1998 access

*Corresponding author: Ojekunle OZ, Federal University of Agriculture, Abeokuta, Ogun State, Nigeria, Tel: 080-23215468/23215519; Fax: 080-23217008; E-mail: oojekunle@yahoo.com

Received September 11, 2017; Accepted September 22, 2017; Published September 26, 2017

Citation: Ojekunle OZ, Lateef ST (2017) Environmental Impact of Abattoir Waste Discharge on the Quality of Surface Water and Ground Water in Abeokuta. J Environ Anal Toxicol 7: 509. doi: 10.4172/2161-0525.1000509

Copyright: $\odot 2017$ Ojekunle OZ, et al. This is an open-access article distributed under the terms of the Creative Commons Attribution License, which permits unrestricted use distribution, and reproduction in any medium, provided the original author and source are credited. 
Citation: Ojekunle OZ, Lateef ST (2017) Environmental Impact of Abattoir Waste Discharge on the Quality of Surface Water and Ground Water in Abeokuta. J Environ Anal Toxicol 7: 509. doi: 10.4172/2161-0525.1000509

Page 2 of 6

the total amount of waste produced per animal slaughtered to be approximately $35 \%$ of its weight. About $6 \mathrm{~kg}$ of manure is produced for every $1000 \mathrm{~kg}$ of carcass weight, a slaughtered beef produces (excluding rumen contents or stockyard manure) and $100 \mathrm{~kg}$ of paunch manure (partially digested food) [5].

Abattoir effluents whether it reaches the water body through a point source or nonpoint source reduce oxygen in water and endanger aquatic life and can leads to life threatening effect. The organic nutrients added to ground water produce excessive microbial growth causing unpleasant taste and odours of water from this source.

\section{Materials and Methods}

\section{Study area}

The study area for this project is Abeokuta. Abeokuta is the capital and largest city of Ogun State with Coordinate: Latitudes $\left(7^{\circ} 5^{\prime} 35^{\prime \prime} \mathrm{N}\right.$ to $7^{\circ} 20^{\prime} \mathrm{N}$ and Longitudes $3^{\circ} 17^{\prime} \mathrm{E}$ to $\left.3^{\circ} 27^{\prime}\right)$.

\section{Sampling collection}

Water samples were collected randomly in 9 different locations of Abeokuta (4 samples from stream and 3 from ground water i.e., well around abattoir vicinity and 2 controls of surface water and groundwater). All the samples were collected on the same day in the morning for various physical, chemical and micro-biological analysis. Water samples were collected into nine (2 litres) clean dry plastic bottles in a way that the water will not mix with any other from another source. Each water sample were collected at the monitoring stations for laboratory analysis using a sample container which will helps to prevent losses due to adsorption, volatilization and contamination by foreign substances. Sample bottles were rinsed twice with the water obtained from designated stream and well prior to collecting samples for testing and the sample bottles were filled completely to prevent any loss of dissolved gases from the water samples. The plastic containers are labelled appropriately using a marker with the information on collection point which will be cross-checked with the field notebook and the sample collection sheet and transported to the laboratory. Water samples were preserved in a refrigerator with a temperature between $0^{\circ} \mathrm{C}$ and $4^{\circ} \mathrm{C}$. The water quality parameters measured includes; Color, Odor, $\mathrm{pH}$, Temperature, Total Dissolve Solids (TDS), Chloride $(\mathrm{Cl})$, Dissolved Oxygen, Biochemical Oxygen Demand (BOD), Chemical Oxygen Demand (COD), Total Solids, Total Suspended Solids, Nitrate, Heavy Metals (Lead, Zinc, Copper, Cadmium and Iron), microbiological analysis (Figure 1).
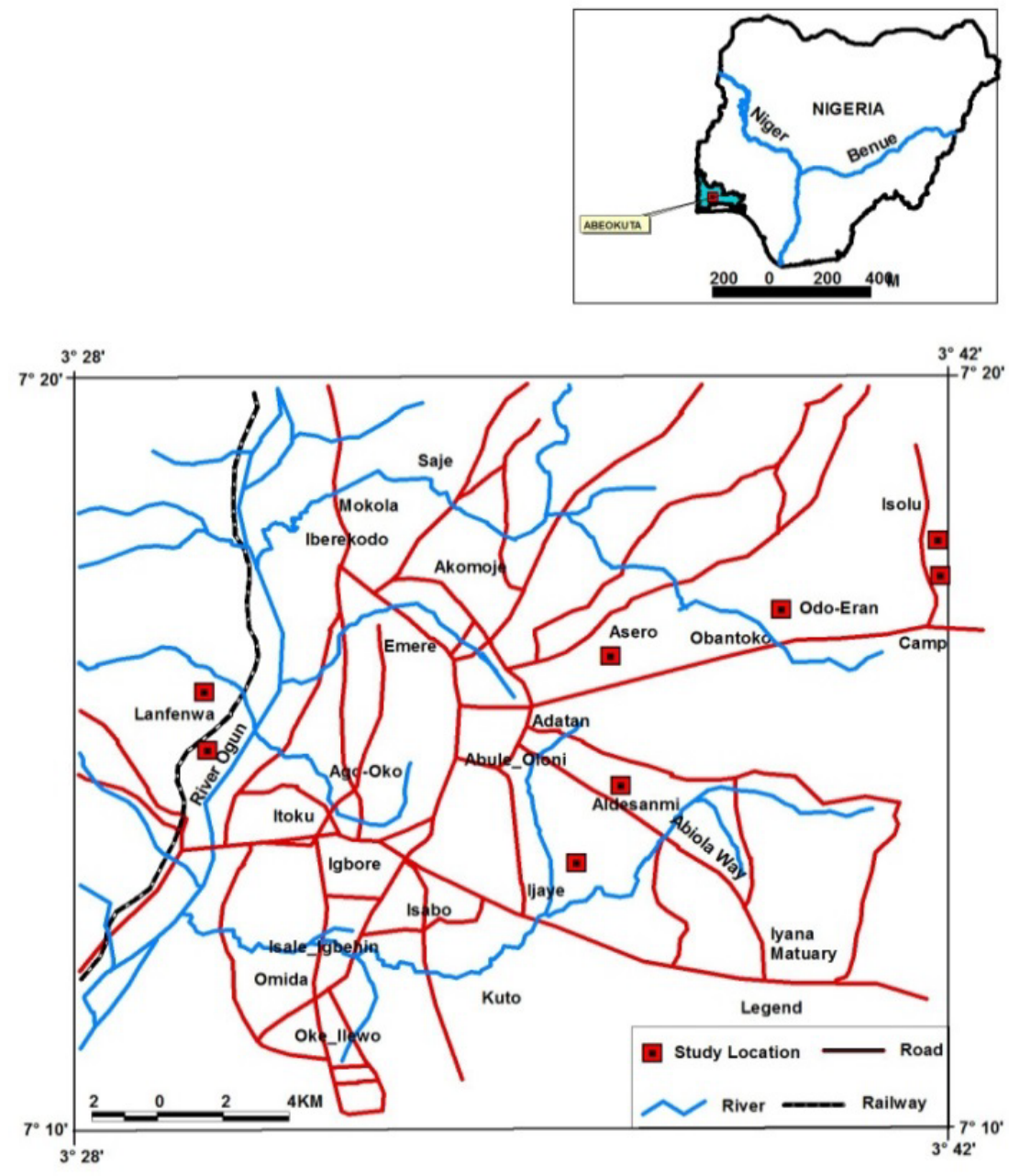

Figure 1: Map showing the sampling location of abattoir in Abeokuta, Ogun State. Source: Cartographic lab. (FUNAAB 2015). 
Citation: Ojekunle OZ, Lateef ST (2017) Environmental Impact of Abattoir Waste Discharge on the Quality of Surface Water and Ground Water in Abeokuta. J Environ Anal Toxicol 7: 509. doi: 10.4172/2161-0525.1000509

Page 3 of 6

Physical and Chemical parameters were determined by instrumental methods and conducted following standard analytical method (APHA 1995). Cationic and anionic constituents were determined by standard titrimetric and spectrophotometric methods, trace and heavy water were determined by Atomic Adsorption Spectrophotometer. The physico-chemical analysis of the various water quality parameters results as well as other heavy and microbial load will be compared with WHO (World Health Organisation, 1997) drinking water quality guideline.

\section{Results and Discussion}

The temperature of the samples ranges between $27.8^{\circ} \mathrm{C}-28.3^{\circ} \mathrm{C}$ (Figure 2), these range in results are similar to the study done by Magaji et al. [6,7]. who identified in it study of most abbatoir area with temperature of $28.5^{\circ} \mathrm{C}-28.8^{\circ} \mathrm{C}$. The temperature falls within the WHO standard of permissible limit of $<40^{\circ} \mathrm{C}$, and is lower than $32^{\circ} \mathrm{C}$ to $34^{\circ} \mathrm{C}$. Temperature influences the amount of dissolved oxygen in water which in turn influences the survival of aquatic organisms.

The $\mathrm{pH}$ ranged from 7.24-7.63 with a mean value of 7.51 (Figure 3) falls within WHO standards of 6.5-8.5 compares with 4.9 to 7.2 reported by Masse and Masse on similar study where all the samples were slightly alkaline [8]. Therefore, the water samples were unlikely to cause health problems such as acidosis [9]. However, $\mathrm{pH}$ played a significant role in determining the bacterial population growth and diversity in surface water. Microorganisms frequently change the $\mathrm{pH}$ of their own habitat by producing acidic or basic metabolic waste products [10].

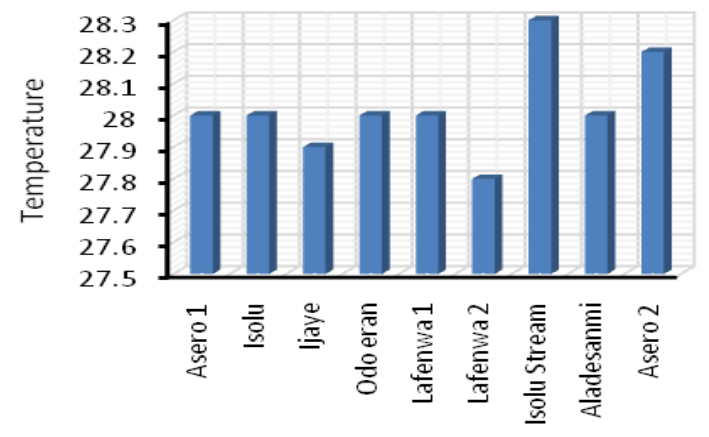

Sample Location

Figure 2: The temperature level of the Sample water.

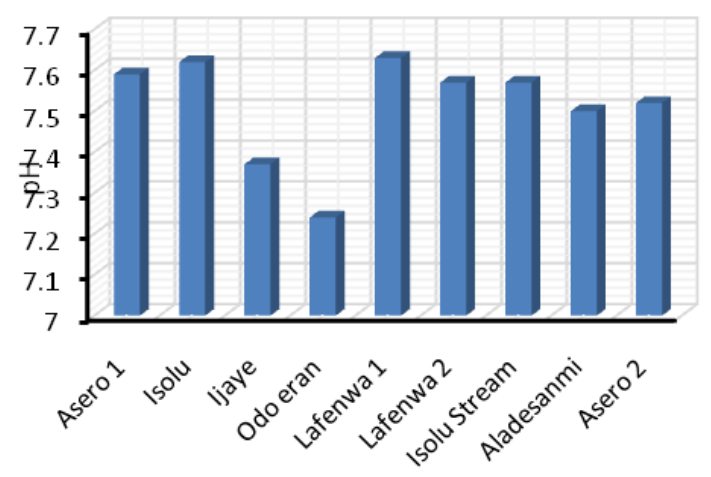

Sample Location

Figure 3: The $\mathrm{pH}$ level of the Sample water.
The TDS value of the result obtained from the analysis Ijaye well has the highest value of $323 \mathrm{mg} / \mathrm{L}$ while Lafenwa (100 m away from point of discharge) has lowest value of $75 \mathrm{mg} / \mathrm{L}$, although the values ranged from $75 \mathrm{mg} / \mathrm{L}$ to $323 \mathrm{mg} / \mathrm{L}$ (Figure 4). All value obtained falls below WHO standard of $<1200 \mathrm{mg} / \mathrm{L}$. High significant values of TDS could be due to salt water intrusion because of proximity to the oceans [11]. Most often, high levels of TDS are caused by the presence of potassium, chlorides and sodium and interfere with the taste of foods and beverages, and makes them less desirable to consume. Some of the individual mineral salts that makeup TDS pose a variety of health hazards to living organisms and as reported by Efe are an indication of the degree of dissolved substances such as metal ions in the water [12].

Electrical conductivity is the ease to which a substance allows free flow of electricity through the ions in electrolytes of water sample. The values of EC ranged from 184 to $631 \mu \mathrm{s} / \mathrm{cm}$, were Ijaye well has the highest value while Lafenwa (100 $\mathrm{m}$ away from point of discharge) recorded lowest (Figure 5). All the samples were within the permissible limits of WHO maximum permissible level of the conductivity of $900 \mu \mathrm{s} / \mathrm{cm}$. This shows that the water samples are not saline, the concentration of salts dissolved in the water is minimal, and the salt content of a water body is determined by its ability to conduct an electric current the higher the salt concentration, the larger the current that can be conducted and the higher the EC of the water. Any level above WHO standards can pose health risk of defective endocrine functions and also total brain damage with prolonged exposure. All the water samples have their EC values less than the highest tolerable values.

The TS values of all samples analysed ranges from 0.76 to $3.4 \mathrm{mg} / \mathrm{L}$. There is no evidence of any epidemiological reaction at high level of Total solids, but water becomes unpalatable and may lead to corrosion of containers. Consequently, WHO set the highest permissible values

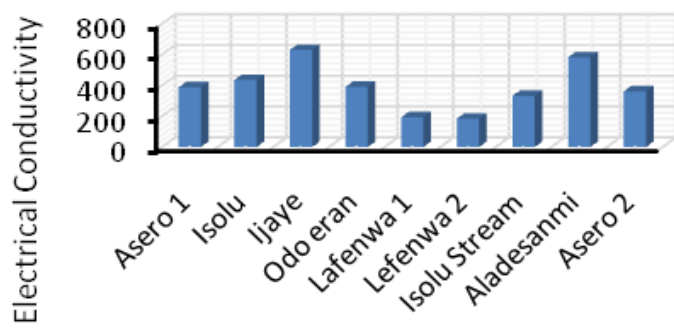

Sample Location

Figure 4: The TDS level of the Sample water.

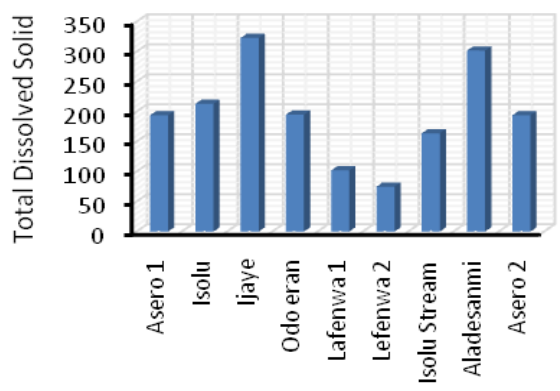

Sample Location

Figure 5: The EC level of the Sample water 
Citation: Ojekunle OZ, Lateef ST (2017) Environmental Impact of Abattoir Waste Discharge on the Quality of Surface Water and Ground Water in Abeokuta. J Environ Anal Toxicol 7: 509. doi: 10.4172/2161-0525.1000509

Page 4 of 6

of $1000 \mathrm{mg} / \mathrm{L}$. The palatability of water with a total solids level of less than $1000 \mathrm{mg} / \mathrm{L}$ is generally considered to be good.

TSS values ranged from 15.20 to $16.14 \mathrm{mg} / \mathrm{L}$ with mean values of $15.74 \mathrm{mg} / \mathrm{L}$ which falls within the WHO maximum permissible limit for TSS $(30 \mathrm{mg} / \mathrm{L})$. TSS relatively measures the physical or visual observable dirtiness of a water resource.

Values obtained for BOD from the analysis carried out, it was observed that (Asero 2) has the highest value of $12.2 \mathrm{mg} / \mathrm{L}$ while (Aladesanmi) has lowest value of $1.5 \mathrm{mg} / \mathrm{L}$ (Figure 6). The BOD is an important water quality parameter and is very essential in water quality assessment. Growth of aerobic and facultative anaerobic bacteria will be enhanced by the presence of dissolved oxygen in any water body. The BOD values range from 1.5-12.2 $\mathrm{mg} / \mathrm{L}$. All the values of BOD samples are within the permissible standard the WHO standard of 50 $\mathrm{mg} / \mathrm{L}$ for waste water. The more organic material presents in the river the higher the BOD thus showing variance with the result of Ojekunle et al. [13].

The DO is a measure of the degree of pollution by organic matter, the destruction of organic substances as well as self-purification capacity of the water body (Figure 7). The standard for sustaining aquatic level is $5 \mathrm{mg} / \mathrm{L}$. Concentration below this value adversely affect aquatic biological life, while concentration below $2 \mathrm{mg} / \mathrm{L}$ may lead to death of most fishes, [14]. The higher the concentration of DO the better the water quality. The DO values ranges from 1.0-6.8 $\mathrm{mg} / \mathrm{L}$. (Asero 1) and (Asero 2) has high DO of 5.4 and $6.8 \mathrm{mg} / \mathrm{L}$ as a result of Abattoir waste and Tie and Dye activities carried out in the area (Lafenwa 1) and (Isolu Stream) also has high DO values of 4.4 and $3.9 \mathrm{mg} / \mathrm{L}$ though the other values at other points re within

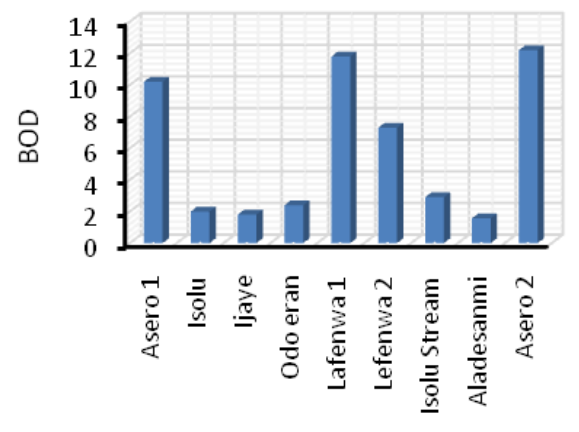

Sample Location

Figure 6: The BOD level of the Sample water.

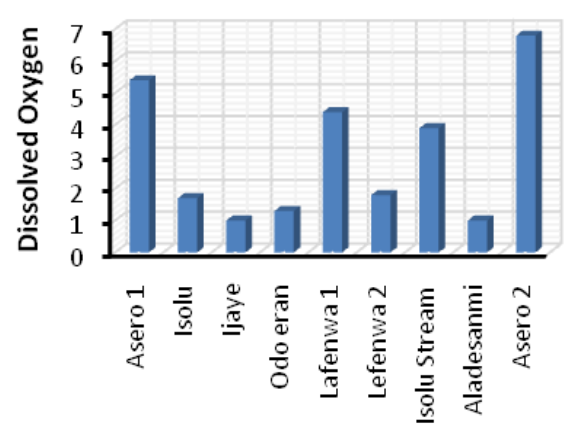

Sample Location

Figure 7: The DO level of the Sample water. the expected WHO value of $2.0 \mathrm{mg} / \mathrm{L}$, two points namely Ijaiye and Aldesanmi are experiencing hypoxia which are complete variance with the study carried out by Ojekunle et al. on similar abattoir study $[13,15]$.

The COD values have it highest concentration of $80 \mathrm{mg} / \mathrm{L}$ at Asero 1, Isolu, Aladesanmi and Asero 1 while it was not detected in other points, although all these values were within the permissible limit standard of $1000 \mathrm{mg} / \mathrm{l}$ (WHO 2006). High level of COD indicates the presence of chemical oxidants in the effluent while low COD indicates otherwise. High COD could likely cause nutrient fixation in the soil resulting to reduce rate of nutrients fixation in the soil resulting to reduced rate of nutrient availability to plants. Chemical oxidants affect water treatment plants by Chemical oxidants affects water treatment plants by causing rapid development of rust [15].

From the result obtained from the analysis (Figure 8) total hardness ranged from 102-518 $\mathrm{mg} / \mathrm{L}$. (Asero 1 ) has the highest value of $518 \mathrm{mg} / \mathrm{L}$ while (Lefenwa 2) has the lowest value. All the values exceeded WHO permissible limit of $100 \mathrm{mg} / \mathrm{L}$. Abattoir wastewater contribute to the elevated total hardness values, exposure to hard water has been suggested to be a risk factor that could exacerbate eczema. The environment plays an important part in the etiology of atopic eczema. A suggested explanation relative to hard water is that increased soap usage in hard water results in metal or soap salt residues on the skin (or on clothes) that are not easily rinsed off and that lead to contact irritation especially to local users.

The chloride values range from $20-71 \mathrm{mg} / \mathrm{L}$ (Figure 9) which falls within the WHO standard of $<250 \mathrm{mg} / \mathrm{L}$ ). The little concentration of $\mathrm{C}_{12}$ was basically due to the diffusion of ocean water into the river as a result of tidal action [16]. The chloride sources could be soluble salt $(\mathrm{NaCl}$ and $\mathrm{KCl})$.

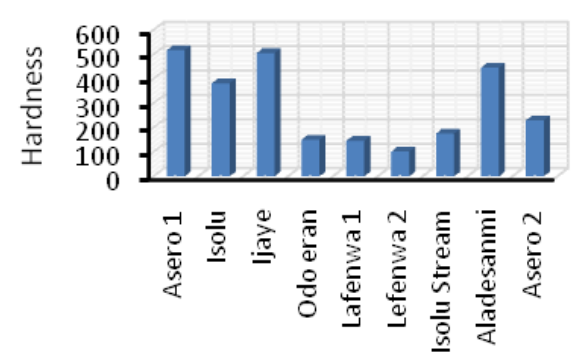

Sample Location

Figure 8: The total hardness level of the Sample.



Figure 9: The $\mathrm{Cl}$ level of the Sample water. 
Citation: Ojekunle OZ, Lateef ST (2017) Environmental Impact of Abattoir Waste Discharge on the Quality of Surface Water and Ground Water in Abeokuta. J Environ Anal Toxicol 7: 509. doi: 10.4172/2161-0525.1000509

Page 5 of 6

From the phosphate result obtained from the analysis shown, (Ijaiye) possesses the highest value of $0.850 \mathrm{mg} / \mathrm{L}$ while has lowest value of $0.212 \mathrm{mg} / \mathrm{L}$. Although from the analysis the values ranged from 0.212 to $0.850 \mathrm{mg} / \mathrm{L}$ which were within WHO maximum permissible value of $0-5 \mathrm{mg} / \mathrm{L}$. Wastewater treatment into tertiary waste could lead to a decline in phosphorous concentration according to the work carried out by Correll, 1998, in Lake Leman [17]. Nitrate is a nitrogenous compound that when it is in excess in our drinking water can cause reduction of oxygen capacity of blood, shortness of breath and blueness of skin. From the nitrate value obtained, the concentration ranged between $0.074-0.705 \mathrm{mg} / \mathrm{L}$ values below the WHO guideline value of $50 \mathrm{mg} / \mathrm{L}$ and if exceeded it is regarded as one of the causes of methamoglobin-anaemia (Blue Baby Syndrome) in infants as well as a potential risk of stomach cancer in adults. High concentration of nitrate in both surface and shallow groundwater can probably due to poor sanitation and latrine construction, fertilizer and other agrochemical use.

Sulphate does not have a health-based guideline value. The sulphate value obtained ranged between $0.64-68.24 \mathrm{mg} / \mathrm{L}$ however the WHO recommends that a concentration higher than $450 \mathrm{mg} / \mathrm{L}$ is unhygienic due to problems to the gastro intestinal tract. All the water samples collected have their Sulphate values lower than the limit. This may be attributed to the depth and the concrete slab on which prevent abattoir effluents having access into them.

The concentration of $\mathrm{Cu}$ obtained ranged between $0.01-0.03 \mathrm{mg} / \mathrm{L}$. Isolu stream has the highest value of $0.03 \mathrm{mg} / \mathrm{l}$ while 5 other points making up $70 \%$ has the lowest value of $0.01 \mathrm{mg} / \mathrm{L}$ (Figure 10). All the results are below the WHO standard of $1.0 \mathrm{mg} / \mathrm{L}$.

Iron concentration in the collected samples ranged between 0.46 $4.96 \mathrm{mg} / \mathrm{L}$ (Figure 11) and it is above the maximum contaminant levels of the iron content based on WHO of $0.3 \mathrm{mg} / \mathrm{L}$. This implies that if the abattoir discharges its wastewater into other water bodies used for drinking purposes downstream, it could be a contaminant and hence, hazardous to human health. Despite not being a health concern, high concentration of iron affects the quality of water, leading to bad taste and colouration of cooking utensils and food. There is no noticeable taste at iron concentration below $0.3 \mathrm{mg} / \mathrm{l}$, although turbidity and colour may develop. This high iron content may probably be attributed to influx of waste blood may be carried by runoff and deposited into the streams, shallow wells and boreholes.

The concentration of Zinc ranged between $0.02-0.09 \mathrm{mg} / \mathrm{L}$, In the month of May, Asero 1 has the lowest concentration of Zinc of 0.02

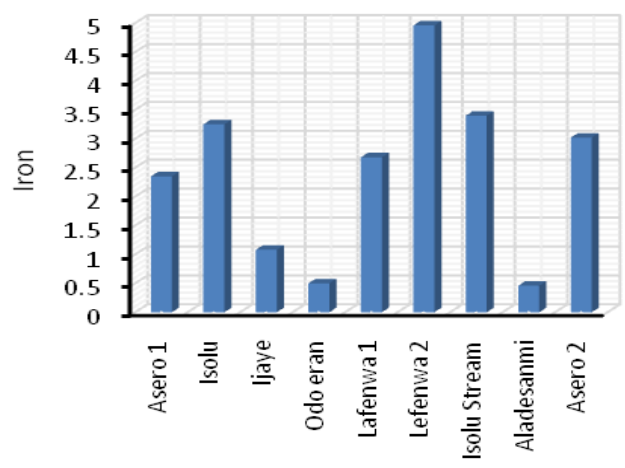

Sample Location

Figure 10: The copper level of the Sample water. $\mathrm{mg} / \mathrm{L}$ while Lafenwa 1 and Lefenwa 2 have the highest concentration of Zinc $(0.09 \mathrm{mg} / \mathrm{L})$ respectively (Figure 12), all of which was within the permissible limit of the WHO standard of $1.5 \mathrm{mg} / \mathrm{L}$. They are within the range reported for African inland waters.

The concentration of Lead found in the water samples from the water sample range from $0.03-0.19 \mathrm{mg} / \mathrm{L}$ and it exceeded the permissible WHO limit of $0.1 \mathrm{mg} / \mathrm{L}$, thus, it could be attributed to dilution from the dump site and discharging of abattoir effluent into the water bodies (Figure 13).

The presence of total coliform provides evidence of recent faecal contamination and the detection should lead to further action. It is

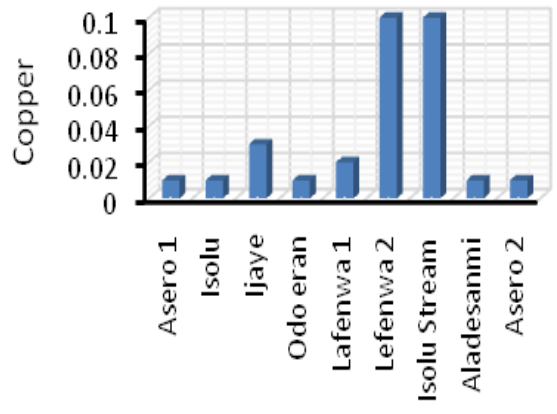

Sample Location

Figure 11: The Iron level of the Sample water.

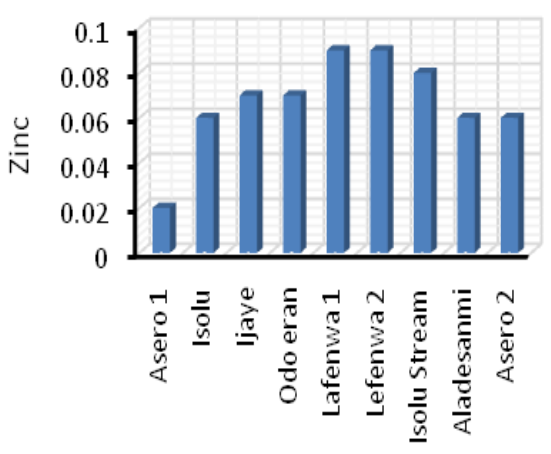

Sample Location

Figure 12: The Zinc level of the Sample water.

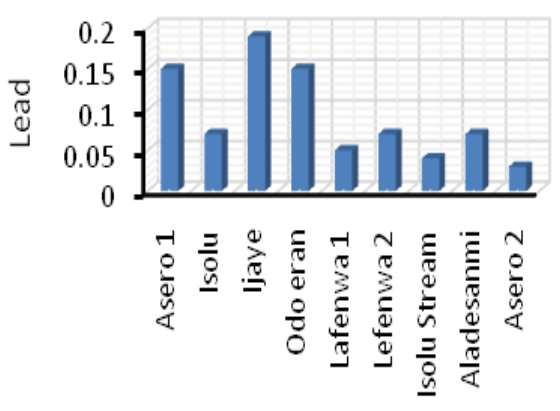

Sample Location

Figure 13: The Lead level of the Sample water. 
Citation: Ojekunle OZ, Lateef ST (2017) Environmental Impact of Abattoir Waste Discharge on the Quality of Surface Water and Ground Water in Abeokuta. J Environ Anal Toxicol 7: 509. doi: 10.4172/2161-0525.1000509

Page 6 of 6

present in high number in human and animal faeces and rarely found in the absence of faecal pollution. From the TFC values obtained from (Figure 14). Ijaiye abattoir has the highest value of $300 \mathrm{cfu} / \mathrm{ml}$ while lafenwa 1 has the lowest value of almost nil. The presence of coliform reveals regrowth and possible biofilm function or contamination. They occur in both sewage and natural wastes and can also be excreted with human and animal faeces. WHO (2006) recommends zero values for total coliform. However, none of the water samples taken are free from these bacteria Lafenwa 1 . This implies that there is possibility of additional pollutants from humans operating within and around the abattoir thus the drainage outside the abattoir is more polluted than that within the abattoir. This result corroborates Coker et al. that abattoir wastewater is heavily polluted regardless of the point from which it is taken from [3].

\section{Conclusion}

The major source of surface and groundwater pollution is indiscriminate discharge of untreated abattoir effluents directly into the ground surface or the surface water bodies resulting in serious surface and groundwater contamination. This loss of water quality is causing health hazards and death of human beings. This problem is aggravated by inadequate awareness, scarce financial resources, lack wastewater treatment facilities, and the inefficient ineffective environmental laws. The concentration of the heavy metals verification like $\mathrm{Cd}$, $\mathrm{Pb}, \mathrm{Cu}$ reported above indicate that there is significant difference in the concentration of the pollutants taken at different sample points. Furthermore, the concentration of heavy metals in the sample water was discovered to be significantly higher than the permissible limits of WHO standard, 2006. Although some of the results like EC and TDS are slightly in line with permissible limits of WHO standard, 2006. However, our environment is under threat if the present habit of discharging untreated abattoir wastes continues. The toxic level of harmful materials can aggravate due to the continuous generation of the effluents. This calls for concern, as most of the analysed values were above the recommended standards, which obviously signals danger to human health and that of plants life. Residents living in abattoir vicinity may in no distant time begin to experience severe consequences of pollutants from abattoir activities located in their neighbourhood. It was also found out that the shallow wells water quality in area of Abeokuta abattoir is being contaminated due to the discharge of the effluents from animal processing into the land surface, channels and surface water and eventually finds its way to the groundwater source. This is because of soil porosity, permeability and also the rocks nature of Abeokuta which permits easy movement of ground and surface water. From the analyses, it will be logical to say that the abattoir effluent from

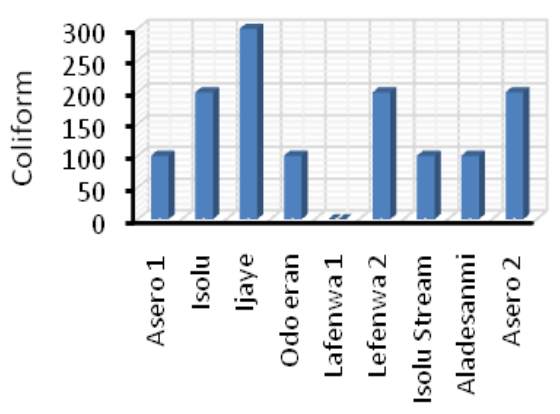

Sample Location

Figure 14: The TFC level of the Sample water. the production meat has its impact on the quality of both the shallow well and river water in the sampling site of the study area (Abeokuta).

\section{References}

1. Omole DO, Longe EO (2008) An Assessment of the Impact of Abattoir Effluents on River Illo, Ota, Nigeria. Environ Sci Techno 1: 56-64.

2. Adesemoye AO, Opere BO, Makinde SCO (2006) Microbial Content of abattoir waste water and its contaminated soil in Lagos, Nigeria. Afr J Biotechnolgy 5: 1963-1968.

3. Coker AO, Olugasa BO, Adeyemi AO (2001) Abattoir Wastewater Quality in South Western Nigeria. Proceeding on the 27th WEDC Conference, Lusaka, Zambia, pp: 329-331.

4. Nafarnda WD, Yayi A, Kubkomawa B (2006) Impact of Abattoir Waste on Aquatic Life: A Case Study of Yola Abattoir. Global J Pure Applied Sci 12: 31-33.

5. Verheijen LAHM, Wiersema LWD, Hulshoff P, DeWit J (1996) Management of Wastes from Animal Product Processing. International Agriculture Center, Wageningen, The Netherlands.

6. Adie GU, Osibanjo O (2007) Impact of Effluent from Bodija Abattoir on the Physicochemical Parameters of Oshunkaye Stream in Ibadan City, Nigeria. Afr J Biotechnolgy 6: 1806-1811.

7. Magaji JY, Chup CD (2012) The Effects of Abattoir Waste on Water Quality in Gwagwalada-Abuja. pp: 542-549.

8. Masse DI, Masse L (2000) Characterization of Wastewater from hog slaughterhouse in Eastern Canada and Evaluation of their in-plant Wastewater treatment systems. Agriculture and Agri-food Canada Contribution No 660.

9. Asamoah DN, Amorin R (2011) Assessment of the Quality of Bottled/Sachet Water in the Tarkwa-Nsuaem Municipality (TM) of Ghana. Res J Appl Sci Eng Technol 3: 337-385.

10. Prescott LM, Harley JP, Klein DA (1999) The Influence of Environmental Factors on Growth. Microbiology. 4th edn. McGraw-Hill Companies Inc., USA, pp: 123-132.

11. Martins O, Awokola OS (1996) Total Dissolved Solids of Selected Rivers in South Western Nigeria. J Min Geol 32: 113-119.

12. Efe ST (2001) An Appraisal of the Quality of Rain and Groundwater Resources in Nigerian Cities. The Case of Warri Metropolis. Unpublished PhD Seminar Paper, Department of Geography and Regional Planning, Delta State University, Abraka, Nigeria.

13. Ojekunle OZ, Ufoegbune GC, Oyebamiji FF, Sangowusi RO, Taiwo AM, et al (2014) Assessment of the effect of commercial activities on the surface water quality on Ogun river.

14. Chapman D (1992) Water Quality Assessments, a Guide to the Use of Biota Sediments and Water in Environment Monitoring. 1st edn. UNESCO/WHO/ UNEP. Chapman and Hall London, pp: 371-460.

15. Chukwu O (2008) Analysis of Groundwater Pollution from Abattoir Waste in Minna, Nigeria. J Dairy Sci 2: 74-77.

16. Ahonkhai SI, Chukwuogo El (1996) Effects of Industrial Activities in Warri Area on the Surface Water Quality. In: FEPA Monograph (1996). Water Quality Monitoring and Environmental Status in Nigeria. 1: 131-137.

17. Correl DL (1998) The Role of Phosphorus and Eutrophication of Receiving Waters. A Review. J Environ Qual 27: 261-266. 